Asian J Agric \& Biol. 2022(1).

$\mathrm{AJAB}$

DOI: $10.35495 / a j a b .2021 .01 .043$

Original Article

\title{
Effect of sowing techniques and tillage practices on paddy yield of direct seeded rice in salt affected soils
}

\author{
Muhammad Rizwan, Khalil Ahmed*, Muhammad Khalid Bhatti, Muhammad Sarfraz, Muhammad Irfan, \\ Syed Saqlain Hussain, Abdul Rasul Naseem \\ Soil Salinity Research Institute (SSRI), Pindi Bhattian, Pakistan
}

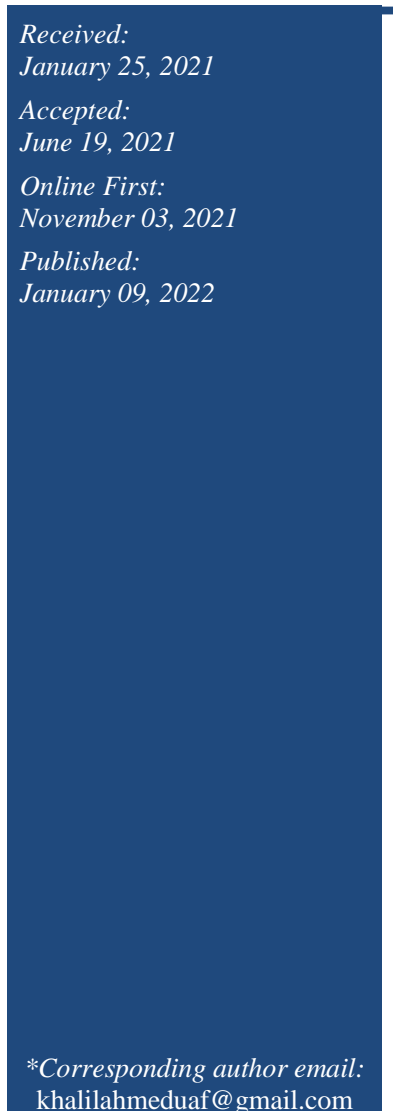

\begin{abstract}
In the scenario of labor and water shortage, direct sowing of rice is a promising and alternative strategy for rice establishment. Therefore, a field study was undertaken to evaluate the comparative efficiency of different sowing methods and tillage practices for direct seeded rice in salt affected soil. The following treatments tested were; $\mathrm{T}_{1}$ : cultivator, $\mathrm{T}_{2}$ : disk harrow + cultivator, $\mathrm{T}_{3}$ : rotavator + cultivator, with three sowing techniques; $\mathrm{S}_{1}$ : broadcast + seed covering with planking $40 \mathrm{~kg}, \mathrm{~S}_{2}$ : broadcast + seed covering with planking $60 \mathrm{~kg}$ and, $S_{3}$ : drill sowing. The experiment was designed in randomize complete block design having split plot arrangement and three replications. Results of the study showed that maximum paddy yield was recorded by drill sowing with rotavator + cultivator used as tillage implements for land preparation. At the end of the study, soil properties were also improved with reduction of $0.57 \%, 16.21 \%$ and $8.56 \%$ in $\mathrm{pH}_{\mathrm{s}}, \mathrm{EC}_{\mathrm{e}}$ and $\mathrm{SAR}$ respectively with use of rotavator + cultivator and drill sowing. In conclusion, use of rotavator + cultivator as tillage implement and drill sowing is effective and feasible technology for direct sowing of rice in salt affected soils.
\end{abstract}

Keywords: Broadcast, Direct seeding, Drill sowing, Rice, Rotavator

\section{How to cite this:}

Rizwan M, Ahmed K, Bhatti MK, Sarfraz M, Irfan M, Hussain SS and Naseem AR, 2022. Effect of sowing techniques and tillage practices on paddy yield of direct seeded rice in salt affected soils. Asian J. Agric. Biol. 2022(1): 202101043. DOI: https://doi.org/10.35495/ajab.2021.01.043

This is an Open Access article distributed under the terms of the Creative Commons Attribution 3.0 License. (https://creativecommons.org/licenses/by/3.0), which permits unrestricted use, distribution, and reproduction in any medium, provided the original work is properly cited.

\section{Introduction}

The low permeability of surface soil due to compaction is a well-known problem in agriculture (Hamza and Anderson, 2005) and this situation may become worsened in salt affected soil due to accumulation of soluble salts in rhizosphere. A hyper saline environment may create unfavorable soil conditions for crop growth and development. Tilling is a field operation to manipulate the soil for a sustainable desired structure (Nayel et al., 2016). Tillage operations depend on soil properties like porosity, compaction, infiltration rate, bulk density and specific crop (Ashraf et al., 2003). Therefore, the selection of specific tillage system is very crucial that improves and maintain the soil conditions required for favorable crop growth (Mosaddeghi et al., 2009; $\mathrm{Ji}$, 2013). In salt affected soil during the land 
preparation, choice of tillage implements is very critical which not only reduce the root resistance but also facilitate the leaching of soluble salts out of root zone. The use of suitable tillage implement during the land preparation creates ideal conditions for root penetration and development and seedling emergence (Licht and Al-Kaisi, 2005).

In a field study, Azhar et al. (2001) evaluated the effect of different tillage implements (sub-soiler, narrow-tine cultivator, disk plough and chisel plough,) during the land preparation of salt affected soil. They opined that subsoiler was the most effective tillage implements to reduce the soil electrical conductivity, exchangeable sodium percentage, $\mathrm{pH}_{\mathrm{s}}$, bulk density, infiltration rate, and soil penetration resistance. According to Ahmed et al. (2015) disc plough with farmyard manure and gypsum improved deteriorated properties (electrical conductivity, sodium absorption ratio, $\mathrm{pH}_{\mathrm{s}}$, bulk density and hydraulic conductivity) of salt affected soils and yield of fodder beet. Amin et al. (2014) studied the comparative performance of rotavator, chisels plow, disk plow, tine cultivator and moldboard plow. They concluded that moldboard plow and chisel plow were more effective tillage implements in improving the soil penetration resistance, bulk density and moisture contents. Similarly, Aikins and Afuakwa (2012) concluded that disc ploughing followed by disc harrowing is a very effective tillage practice for improving yield of cowpea and soil properties.

Rice is the major food crop for more than $50 \%$ of the world's population, and is grown in more than 95 countries across the globe (Coats, 2003; IRRI, 2002). To fulfill the global rice demand, rice production should be increased by $26 \%$ in the next 20 years (IRRI, 2003). However, environmental abiotic stress like salinity hampers the yield of rice (Moon et al., 2011; Guo et al., 2015). Different researchers reported that rice yield start to decrease when electrical conductivity of soil is $\mathrm{EC}_{\mathrm{e}}>3 \mathrm{dS} \mathrm{m} \mathrm{m}^{-1}$ (Pearson, 1959; Maas and Hoffman, 1977). Significant loss of rice yield in salt affected soil have been extensively reviewed (Guo et al., 2015; Hoang et al., 2016; Amini et al., 2016). Ideal conditions favorable for plant growth in normal soils are, $\mathrm{pH}=$ 4.5-7.5, sodium absorption ratio $=(\mathrm{SAR})<15$ and electrical conductivity (EC) $<4 \mathrm{dS} \mathrm{m}^{-1}$ (Bohn et al., 1985). However, Salt-affected soils has high $\mathrm{EC}_{\mathrm{e}}, \mathrm{pH}$, and SAR value than normal soils. These poor physical and chemical properties associated with high salinity are the major constraints for the use of saltaffected soil for agricultural production (Guo et al., 2015). Excess of sodium in salt affected soils creates the unfavorable conditions for soil aggregation, resulting in poor soil aeration, low porosity and infiltration, and high bulk density (Dikinya et al., 2006). At higher salt stress, plant growth is affected by two types of stresses i.e., osmotic effect and ionic stress (Castillo et al., 2007). The osmotic stress inhibits the plant access to soil water whereas in specific ion toxicity, levels of toxic ions like sodium, chloride reaches a level that interfere the various metabolic and physiological process (Munns and Tester, 2008; Nishimura et al., 2011). Excessive amount of sodium in plant tissue reduced photosynthetic rate, caused the membrane disruption, reduced chlorophyl contents, interfering antioxidant enzymatic activity, and consequently these changes lead to plant cell death (Cha-umi et al., 2009; James et al., 2011; Siringam et al., 2011). In rice, panicle initiation to flowering stages are considered most susceptible to salinity (Moradi et al., 2003). Nevertheless, all the growth stages of rice plants may be affected by salt stress which results in reduced number of tillers, plant height and finally the paddy yield (Eynard et al., 2005). According (Jini and Joseph, 2017) to salt stress experienced by rice plants reduced the germination rate, number of panicles per plant and 1000 grain yield. Various studies revealed that salt stress may cause reduced rice stand density (Zeng and Shannon, 2000), sterility of panicle (Abdullah et al., 2001) and reduced 1000-grain weight (Farshid and Hassan, 2012). Selection of suitable tillage practice may increase the rice yield in salt affected soil by breaking salt crust, leaching of toxic salts out of root zone, uniform root distribution and improving water holding capacity of soil (Montoroi et al., 1993; Lee et al., 1999; Eynard et al., 2005). According to Pearce et al. (1999) and Wilson et al. (2000) tillage practice in salt affected soil increased the rice yield by $>1 \mathrm{tha}^{-1}$. Nam and Kwon (1999) reported that rice yield increased by $10 \%$ due to positive effect of tillage in salt affected soil of Korea.

Traditional method of rice cultivation is transplanting of 20-25 days old rice seedlings in flooded field. However, 39 million ha of irrigated rice in Asia, may suffer from water scarcity by 2025 (Tuong and Bouman, 2003). Hence, water shortage governed by climate change and expensive labor are major constraints in productivity and sustainability of 
transplanted-flooded rice. Therefore, replacing the transplanted-flooded rice with direct seeded rice may be a suitable option that may save water and labor by $50 \%$ and provides an exhilarating opportunity to adapt to the climate change scenario of Pakistan. Reports of many studies claim comparable or even higher yield of direct seeded rice than transplanted rice if good management practices are adopted. In a study, Zhao et al. (2007) documented 25-50\% lower water use and $5.33 \%$ more grain yield in directseeded rice as compared to transplanted rice. Similarly, Zhu (2008) reported a $22 \%$ higher grain yield in direct-seeded rice than transplanted rice. Sarkar et al. (2003) in a study recorded a grain yield of $3.15 \mathrm{t} \mathrm{ha}^{-1}$ in direct seeded rice while transplanted rice produced a grain yield of $2.99 \mathrm{t} \mathrm{ha}^{-1}$, which was attributed to lower sterility\%, more 1000 grain weight and increased panicle number in direct seeded rice. In addition, less water consumption, labor saving, higher economic returns, faster and easier to plant, less methane emissions, having shorter duration and conducive to mechanization make the direct seeded rice an alternative method of planting instead of conventional method of rice transplanting in flooded rice (Pathak et al., 2011; Kaur and Singh, 2017).

Direct seeding of rice in dry soil is usually practiced by drill sowing, dibbling, broadcasting or with drum seeder (Balasubramanian et al., 2003). Broadcast method requires the seed covering so that seed should be not susceptible to birds or rats. Jackson et al. (2017) observed that drill sowing of rice produced a higher grain yield of $4590 \mathrm{~kg} \mathrm{ha}^{-1}$ against broadcast method with grain yield of $3490 \mathrm{~kg} \mathrm{ha}^{-1}$. Similarly, in a field study, Kumar and Ladha (2011) opined that drill sowing of rice is a superior method in terms of grain yield, weed control and crop establishment over broadcast method. Xangsayasane et al. (2019) concluded that drill sowing of direct seeded rice produced more yield than broadcasting. Singh (2008) compared the different methods of rice establishment. He reported that drill sowing of rice produced a grain yield of $7.82 \mathrm{tha}^{-1}$ as compared to transplanting with grain yield of $5.97 \mathrm{t} \mathrm{ha}^{-1}$. Drill sowing save seed and labor cost, and facilitates weed control due to line sowing as compared to other methods of sowing (Sengxua et al., 2019). In drill sowing, seed can be sown in deeper soil surface with high moisture content, and hence plant can emerge from deeper surface that would be an advantage of drill sowing over broadcast method in dry season (Ohno et al.,
2018), while in broadcast method, seed fall on dry surface and may suffer the moisture stress (Gopal et al., 2010). Crop lodging is a very common problem in direct seeded rice; however, lodging can be reduced to less than $10 \%$ using a seed drill (Rickman et al., 1999). In drill sowing, seed rate can be reduced without any significant loss in yield, because in drill sowing a precise row to row spacing is maintained, whereas in broadcasting it is difficult to maintain the seed rate as the seeds fall continuously (Gopal et al., 2010).

Therefore, keeping the above aspects in consideration, the current study was conducted with an objective to evaluate the best sowing techniques and efficient use of tillage implement for better performance of direct seeded rice in salt affected soil.

\section{Material and Methods}

\section{Experimental site}

A field study was carried out at Soil Salinity Research Institute research farm (altitude $184 \mathrm{~m}$, latitude $31.8950^{\circ} \mathrm{N}$ and longitude $73.2706^{\circ} \mathrm{E}$ ), Pindi Bhattian from 2015 to 2016 . A salt affected field was selected (Table 1) and prepared by using three tillage implements i.e., cultivator, disk harrow and rotavator according to the treatment plan. The average weather conditions were: $40.7 \pm 3.5^{\circ} \mathrm{C}$ temperature, $70.6 \pm$ $5.5 \%$ relative humidity, maximum sunshine hours, 14 $\mathrm{h}$ and $10 \mathrm{~min}$.

\section{Experimental design and treatment details}

Treatments tested were; $\mathrm{T}_{1}$ : cultivator, $\mathrm{T}_{2}$ : disk harrow + cultivator, $\mathrm{T}_{3}$ : rotavator + cultivator, with three sowing techniques; $\mathrm{S}_{1}$ : broadcast + seed covering with planking $40 \mathrm{~kg}, \mathrm{~S}_{2}$ : broadcast + seed covering with planking $60 \mathrm{~kg}, \mathrm{~S}_{3}$ : drill sowing. The experiment was designed in a randomized complete block design having split plot arrangement and three replications. Tillage implements were kept in the main plots and seed covering techniques in subplots having size of $12 \mathrm{~m} \times 18 \mathrm{~m}$. During $1^{\text {st }}$ week of June 2015 and 2016 seed of rice (Shaheen Basmati) at the rate of $30 \mathrm{~kg} \mathrm{ha}^{-1}$ was broadcasted in the respective treatment plot and final planking@ 40 and $60 \mathrm{~kg}$ was done to cover seed according to the treatment plan. For drill sowing, rabi drill was used having $23 \mathrm{~cm}$ row to row spacing with depth of 2-3 cm. Fertilizers in the form of urea $(110 \mathrm{~kg} \mathrm{~N} / \mathrm{ha})$, single super phosphate $(90 \mathrm{~kg} \mathrm{P} / \mathrm{ha})$ and sulphate of potash $(60 \mathrm{~kg}$ $\mathrm{K} / \mathrm{ha}$ ) were applied. All the agronomical and 
management practices were carried out uniformly in all the treatments. Field was irrigated according to the crop requirement and in total 16 irrigations were applied throughout a growing season.

\section{Data collection and statistical analysis}

The crop was harvested at maturity and data regarding plant height, number of tillers and paddy yield was recorded. Soil was sampled from upper surface $(0-15 \mathrm{~cm})$ before sowing and after the harvest of crop, composite soil samples were collected, oven dried, passed through $2 \mathrm{~mm}$ sieve and analyzed for $\mathrm{pH}_{\mathrm{s}}, \mathrm{EC}_{\mathrm{e}}$, and SAR (US Salinity Laboratory Staff, 1954). Collected data were subjected to analysis of variance (ANOVA) and treatment means were compared through the least significance difference (LSD) test at $\mathrm{p} \leq 0.05$ (Steel et al., 1997) using STATISTIX 8.1 package software.

Table-1: Initial soil analysis

\begin{tabular}{|l|c|c|}
\hline \multicolumn{1}{|c|}{ Parameter } & Units & $\begin{array}{c}\text { Soil Depth } \\
(\mathbf{0 - 1 5}) \mathbf{c m}\end{array}$ \\
\hline $\mathrm{pH}$ of soil saturated paste $\mathrm{pH}_{\mathrm{s})}$ & - & 8.71 \\
\hline $\begin{array}{l}\text { Electrical conductivity of soil } \\
\text { extract }\left(\mathrm{EC}_{\mathrm{e}}\right)\end{array}$ & $\left(\mathrm{dS} \mathrm{m}^{-1}\right)$ & 4.07 \\
\hline Sodium absorption ratio (SAR) & $\left(\mathrm{mmol} \mathrm{L}^{-1}\right)^{1 / 2}$ & 30.12 \\
\hline Bulk density (BD) & $\left(\mathrm{Mg} \mathrm{m}^{-3}\right)$ & 1.51 \\
\hline Hydraulic conductivity $(\mathrm{HC})$ & $\left(\mathrm{cm} \mathrm{hr}^{-1}\right)$ & 0.49 \\
\hline Organic matter & $\%$ & 0.74 \\
\hline Available potassium & $\mathrm{mg} \mathrm{kg}^{-1}$ & 98 \\
\hline Available phosphorus & $\mathrm{mg} \mathrm{kg}^{-1}$ & 7.20 \\
\hline Textural class & - & sandy loam \\
\hline
\end{tabular}

\section{Results}

\section{First year (2015)}

Results of the study during first year (2015) revealed that plant height of direct seeded rice remained nonsignificant with different sowing techniques, tillage practices and their interaction (Table 2). Among sowing techniques maximum plant height (124.78 $\mathrm{cm})$ was observed in drill sowing, however, it remained non-significant with broadcasting and planking@ @ 40 and 60 kg. Similarly, the maximum plant height $(124.44 \mathrm{~cm})$ was observed in treatment where, disk harrow + cultivator was used as tillage implements and minimum plant $(119.33 \mathrm{~cm})$ was recorded where only cultivator was used as tillage implements. Data regarding the number of tillers showed that sowing techniques significantly affected this attribute and maximum number of tillers (203.11) were divulged with drill sowing followed by broadcasting + planking @ $40 \mathrm{~kg}$ and both the treatments were statistically significant from each other (Table 3). On the other hand, minimum number of tillers (187.67) were produced by broadcasting + planking@ @ $60 \mathrm{~kg}$. Among tillage practices, maximum number of tillers (196.78) were recorded with rotavator + cultivator however, it was nonsignificant from disk harrow + cultivator and only cultivator. Interaction among sowing techniques and tillage implements remained non-significant. Data in table 4 showed that the paddy yield of direct seeded rice was significantly influenced by tillage implements and the maximum mean paddy yield $\left(2.58\right.$ t. ha $\left.^{-1}\right)$ was achieved where rotavator + cultivator was used for land preparation; however, it was statistically $(P \leq 0.05)$ same with treatment where disk harrow + cultivator was used. Minimum paddy yield (1.90 t. ha $\left.{ }^{-1}\right)$ was obtained where only cultivator was used for land preparation. Sowing techniques also affected the paddy yield and maximum paddy yield $\left(2.45 \mathrm{t}\right.$. ha $\left.^{-1}\right)$ was observed with drill sowing, which was statistically higher than broadcasting and planking @ 40 and 60 kg.

Table-2: Effect of sowing techniques and tillage practices on plant height $(\mathrm{cm}) 2015$

\begin{tabular}{|l|c|c|c|c|}
\hline Treatments & $\begin{array}{c}\text { Broadcasting+ } \\
\text { planking @ 40 } \\
\text { kg }\end{array}$ & $\begin{array}{c}\text { Broadcasting+ } \\
\text { planking @ 60 } \\
\text { kg }\end{array}$ & $\begin{array}{c}\text { Drill } \\
\text { sowing }\end{array}$ & Mean \\
\hline Cultivator & $117.33 \mathrm{~B}$ & $119.67 \mathrm{AB}$ & $121.00 \mathrm{AB}$ & $119.33 \mathrm{~B}$ \\
\hline $\begin{array}{l}\text { Disk harrow }+ \\
\text { Cultivator }\end{array}$ & $125.00 \mathrm{AB}$ & $121.67 \mathrm{AB}$ & $126.68 \mathrm{~A}$ & $124.44 \mathrm{~A}$ \\
\hline $\begin{array}{l}\text { Rotavator }+ \\
\text { Cultivator }\end{array}$ & $119.33 \mathrm{AB}$ & $124.00 \mathrm{AB}$ & $126.67 \mathrm{~A}$ & $\begin{array}{c}123.33 \\
\mathrm{AB}\end{array}$ \\
\hline Mean & $120.56 \mathrm{~A}$ & $121.78 \mathrm{~A}$ & $124.78 \mathrm{~A}$ & \\
\hline
\end{tabular}

LSD for tillage implements $=4.7254 \mathrm{LSD}$ for sowing techniques $=6.7580 \mathrm{LSD}$ for Interaction $=8.1847$

Table-3: Effect of sowing techniques and tillage practices on number of tillers $\left(\mathrm{m}^{-2}\right) 2015$

\begin{tabular}{|c|c|c|c|c|}
\hline Treatments & $\begin{array}{c}\text { Broadcasting } \\
\text { + planking @ } \\
\text { 40 kg }\end{array}$ & $\begin{array}{c}\text { Broadcasting+ } \\
\text { planking @ 60 } \\
\text { kg }\end{array}$ & Drill sowing & Mean \\
\hline Cultivator & $183.00 \mathrm{C}$ & $190.33 \mathrm{C}$ & $191.33 \mathrm{BC}$ & $188.22 \mathrm{~A}$ \\
\hline $\begin{array}{c}\text { Disk harrow + } \\
\text { Cultivator }\end{array}$ & $196.00 \mathrm{BC}$ & $186.67 \mathrm{C}$ & $206.00 \mathrm{AB}$ & $196.22 \mathrm{~A}$ \\
\hline $\begin{array}{c}\text { Rotavator + } \\
\text { Cultivator }\end{array}$ & $192.33 \mathrm{BC}$ & $186.00 \mathrm{C}$ & $212.00 \mathrm{~A}$ & $196.78 \mathrm{~A}$ \\
\hline Mean & $190.44 \mathrm{~B}$ & $187.67 \mathrm{~B}$ & $203.11 \mathrm{~A}$ & \\
\hline
\end{tabular}

LSD for tillage implements $=8.9552$ LSD for sowing techniques $=8.5641 \mathrm{LSD}$ for Interaction $=15.511$ 
Table-4: Effect of sowing techniques and tillage broadcasting + planking @ $40 \mathrm{~kg}$ and $60 \mathrm{~kg}$ (Table practices on paddy yield $2015\left(\mathrm{t} \mathrm{ha}^{-1}\right)$

\begin{tabular}{|l|c|c|c|c|}
\hline Treatments & $\begin{array}{c}\text { Broadcasting+ } \\
\text { planking @ 40 kg }\end{array}$ & $\begin{array}{c}\text { Broadcasting+ } \\
\text { planking @ 60 kg }\end{array}$ & $\begin{array}{c}\text { Drill } \\
\text { sowing }\end{array}$ & Mean \\
\hline Cultivator & $1.96 \mathrm{C}$ & $1.80 \mathrm{D}$ & $1.94 \mathrm{C}$ & $1.90 \mathrm{~B}$ \\
\hline $\begin{array}{l}\text { Disk harrow }+ \\
\text { Cultivator }\end{array}$ & $2.53 \mathrm{~B}$ & $2.51 \mathrm{~B}$ & $2.70 \mathrm{~A}$ & $2.57 \mathrm{~A}$ \\
\hline $\begin{array}{l}\text { Rotavator + } \\
\text { Cultivator }\end{array}$ & $2.54 \mathrm{~B}$ & $2.49 \mathrm{~B}$ & $2.73 \mathrm{~A}$ & $2.58 \mathrm{~A}$ \\
\hline Mean & $2.32 \mathrm{~B}$ & $2.26 \mathrm{~B}$ & $2.45 \mathrm{~A}$ & \\
\hline
\end{tabular}

LSD for tillage implements $=0.1182$ LSD for sowing techniques $=0.0604$ LSD for Interaction $=0.1046$

Interaction between tillage implements and sowing techniques showed that maximum paddy yield (2.73 t. $\mathrm{ha}^{-1}$ ) was noted with drill sowing and rotavator + cultivator which was at par with drill sowing and disk harrow + cultivator. Minimum paddy yield (1.80 t. $\mathrm{ha}^{-1}$ ) was documented with broadcasting + planking @ $60 \mathrm{~kg}$ and cultivator was used for land preparation.

\section{Second year (2016)}

Results obtained during 2016 displayed that different tillage practices and sowing techniques could not produce significant effects on plant height (Table 5). Maximum plant height $(126.12 \mathrm{~cm})$ was produced by drill sowing however it was non-significant with broadcasting and planking @ 40 and $60 \mathrm{~kg}$. Comparison of different tillage practices showed that the highest mean value of plant height $(126.11 \mathrm{~cm})$ was observed with disk harrow + cultivator which was at par with rotavator + cultivator. Interaction among the sowing techniques and tillage practices was non-significant.

Table-5: Effect of sowing techniques and tillage practices on plant height $(\mathrm{cm}) 2016$

\begin{tabular}{|l|c|c|c|c|}
\hline Treatments & $\begin{array}{c}\text { Broadcasting } \\
+ \text { planking @ } \\
\mathbf{4 0} \mathbf{~ k g}\end{array}$ & $\begin{array}{c}\text { Broadcasting } \\
+ \text { planking @ } \\
\mathbf{6 0} \mathbf{~ k g}\end{array}$ & $\begin{array}{c}\text { Drill } \\
\text { sowing }\end{array}$ & Mean \\
\hline Cultivator & $119.67 \mathrm{~A}$ & $119.00 \mathrm{~A}$ & $122.33 \mathrm{~A}$ & $120.33 \mathrm{~B}$ \\
\hline $\begin{array}{l}\text { Disk harrow + } \\
\text { Cultivator }\end{array}$ & $128.00 \mathrm{~A}$ & $122.67 \mathrm{~A}$ & $127.67 \mathrm{~A}$ & $126.11 \mathrm{~A}$ \\
\hline $\begin{array}{l}\text { Rotavator + } \\
\text { Cultivator }\end{array}$ & $121.67 \mathrm{~A}$ & $125.00 \mathrm{~A}$ & $128.34 \mathrm{~A}$ & $\begin{array}{c}125.00 \\
\mathrm{AB}\end{array}$ \\
\hline Mean & $123.11 \mathrm{~A}$ & $122.22 \mathrm{~A}$ & $126.12 \mathrm{~A}$ & \\
\hline
\end{tabular}

LSD for tillage implements $=5.4403$ LSD for sowing techniques $=8.1425 \mathrm{LSD}$ for Interaction $=9.4229$

As far as number of tillers were concerned data revealed that sowing techniques had significant effects on this yield component and maximum number of tillers (209.44) were recorded by drill sowing which was significantly higher than by

6). Among tillage practices, maximum number of tillers (202.33) were observed with rotavator + cultivator however, it was non-significant from disk harrow + cultivator and minimum number of tillers (192.44) were noted with only cultivator used for land preparation. Interaction among sowing techniques and tillage implements remained nonsignificant. Results also showed that sowing methods and tillage system had pronounced effect on paddy yield of second direct seeded rice crop and on average more paddy yield was produced in all treatments as compared to paddy yield of first year (Table 7).

Table-6: Effect of sowing techniques and tillage practices on number of tillers $\left(\mathrm{m}^{-2}\right) 2016$

\begin{tabular}{|l|c|c|c|c|}
\hline Treatments & $\begin{array}{c}\text { Broadcasting } \\
+ \text { planking @ } \\
\text { 40 kg }\end{array}$ & $\begin{array}{c}\text { Broadcasting } \\
+ \text { planking @ } \\
\text { 60 kg }\end{array}$ & $\begin{array}{c}\text { Drill } \\
\text { sowing }\end{array}$ & Mean \\
\hline Cultivator & $187.33 \mathrm{C}$ & $193.00 \mathrm{C}$ & $197.00 \mathrm{BC}$ & $192.44 \mathrm{~B}$ \\
\hline $\begin{array}{l}\text { Disk harrow + } \\
\text { Cultivator }\end{array}$ & $202.00 \mathrm{BC}$ & $190.67 \mathrm{C}$ & $212.67 \mathrm{AB}$ & $201.78 \mathrm{AB}$ \\
\hline $\begin{array}{l}\text { Rotavator }+ \\
\text { Cultivator }\end{array}$ & $196.00 \mathrm{C}$ & $192.33 \mathrm{C}$ & $218.67 \mathrm{~A}$ & $202.33 \mathrm{~A}$ \\
\hline Mean & $195.11 \mathrm{~B}$ & $192.00 \mathrm{~B}$ & $209.44 \mathrm{~A}$ & \\
\hline
\end{tabular}

LSD for tillage implements $=9.4735$ LSD for sowing techniques $=8.7889 \mathrm{LSD}$ for Interaction $=16.409$

Table-7: Effect of sowing techniques and tillage practices on paddy yield $2016\left(\mathrm{t} \mathrm{ha}^{-1}\right)$

\begin{tabular}{|c|c|c|c|c|}
\hline Treatments & $\begin{array}{c}\text { Broadcasting+ } \\
\text { planking @ 40 kg }\end{array}$ & $\begin{array}{c}\text { Broadcasting+ } \\
\text { planking @ 60 } \\
\text { kg }\end{array}$ & $\begin{array}{c}\text { Drill } \\
\text { sowing }\end{array}$ & Mean \\
\hline Cultivator & $2.08 \mathrm{C}$ & $1.95 \mathrm{C}$ & $2.06 \mathrm{C}$ & $2.03 \mathrm{~B}$ \\
\hline $\begin{array}{c}\text { Disk harrow } \\
\text { + Cultivator }\end{array}$ & $2.69 \mathrm{AB}$ & $2.65 \mathrm{~B}$ & $2.84 \mathrm{AB}$ & $2.73 \mathrm{~A}$ \\
\hline $\begin{array}{c}\text { Rotavator }+ \\
\text { Cultivator }\end{array}$ & $2.69 \mathrm{AB}$ & $2.75 \mathrm{AB}$ & $2.92 \mathrm{~A}$ & $2.79 \mathrm{~A}$ \\
\hline Mean & $2.49 \mathrm{AB}$ & $2.45 \mathrm{~B}$ & $2.61 \mathrm{~A}$ & \\
\hline
\end{tabular}

LSD for tillage implements $=0.1777$ LSD for sowing techniques $=0.1191$ LSD for Interaction $=0.2063$

On average higher paddy yield of $2.79 \mathrm{t}$. ha ${ }^{-1}$ was documented with rotavator + cultivator, however, it remained same where disk harrow + cultivator was used. The minimum paddy yield of $2.03 \mathrm{t}$. ha ${ }^{-1}$ was recorded where only cultivator was used as tillage implement. Data regarding sowing methods indicated that drill sowing produced the highest paddy yield of $2.61 \mathrm{t}$. ha ${ }^{-1}$ followed by broadcasting + planking @ 40 $\mathrm{kg}$ and both the treatments were statistically $(P \leq$ $0.05)$ alike. Minimum average yield of $2.45 \mathrm{t}^{\mathrm{t}} \mathrm{ha}^{-1}$ was produced by broadcasting + planking @ $60 \mathrm{~kg}$. 
Interactive effect of tillage implements and sowing techniques depicted that maximum paddy yield of direct seeded rice $\left(2.92 \mathrm{t} \mathrm{ha}^{-1}\right)$ was produced by drill sowing and rotavator + cultivator, however, no significant difference was observed where drill sowing and broadcasting were combined with rotavator + cultivator and disk harrow + cultivator. Minimum paddy yield of $1.95 \mathrm{t}$. ha $^{-1}$ was recorded in the treatment where cultivator was used as tillage implements and broadcasting + planking @60 kg was used as sowing method.

\section{Soil properties}

Data also showed that tillage practices considerably reduced the soil salinity and sodicity indices $\left(\mathrm{pH}_{\mathrm{s}}\right.$, $\mathrm{EC}_{\mathrm{e}}$ and SAR) of salt affected field as compared to their initial values at the end of the study. Data regarding soil $\mathrm{pH}_{\mathrm{s}}$ showed that minimum $\mathrm{pH}_{\mathrm{s}} 8.66$ $(0.57 \%$ reduction over its initial value $)$ was noted where rotavator + cultivator was used with drill sowing, whereas, disc harrow + cultivator with drill sowing reduces the $\mathrm{pH}_{\mathrm{s}}$ up to $0.34 \%$ over its initial value (Table 8 ). Similarly, in the case of soil salinity and sodicity maximum reduction of $16.21 \%$ and $8.56 \%$ in $\mathrm{EC}_{\mathrm{e}}$ and SAR respectively was observed where rotavator + cultivator was used as tillage implements for the land preparation and drilling was used as sowing technique (Table 9\&10). Individual use of cultivator was the least effective tillage practice in improving the soil properties.

\section{Discussion}

In direct sowing of rice, soil preparation is a very critical field operation that determines the more appropriate seed placement, the potential of seedlings to emerge from a given depth, improved weed and nutrient management, and seed longevity (Chauhan et al., 2006). In addition, salt affected soils are more compact and denser than normal soil and need to be tilled with site-specific tillage practice, because different tillage systems have different impacts on soil properties and crop growth conditions (Birkas et al., 2008; Jabro et al., 2011). Therefore, an effective and suitable management strategy is required for salt affected soil to restore their deteriorated properties to original potential for crop production. In the current study we used the cultivator as individual or in combination with disc harrow and rotavator to prepare the salt affected field for sowing of direct seeded rice. Results of the study elaborated that use of rotavator + cultivator was the best tillage practice to create favorable soil conditions conducive for germination and growth of direct seeded rice. In saltaffected soils, removal of excessive salts out of root zone is a preliminary requisite to create conditions favorable for successful crop growth. Tilling the soil with rotavator + cultivator facilitates the leaching of toxic salt and dwindled the final value of soil $\mathrm{EC}_{\mathrm{e}}$, $\mathrm{pH}_{\mathrm{s}}$ and SAR (Table 8-10). These lowered values of salinity indices may be the plausible reason for increased paddy yield in this treatment. According to Licht and Al-Kaisi (2005) a suitable tillage package during the land preparation reduces the soil penetration for root emergence and development. In addition, deep tillage increased the water holding capacity and soil permeability, facilitate the removal of toxic salt, cut off the capillary movement and precluded upward movement of soluble salts to the soil surface (Xiong et al., 2012). Comparable findings were reported by Sadiq et al. (2002) that rotavator showed its supremacy over different tillage implement (chisel plough, cultivator and disc plough) in lowering the soil $\mathrm{pH}_{\mathrm{s}}, \mathrm{EC}_{\mathrm{e}}$ and SAR and increased the grain yield of wheat in salt affected soils. Rizwan et al. (2019) also concluded that chisel plough was the most effective tillage implement in increasing the grain yield of wheat and improving soil qualities of saline-sodic soils. Different researchers reported that site-specific tillage practices improved crop yield and soil qualities of salt-affected soils (Sweeney et al., 2005; Amin et al., 2014; Rizwan et al., 2018) which strengthen the findings of the current study. Among sowing methods, drill sowing and broadcasting with 40 and $60 \mathrm{~kg}$ planking were used. Yield analysis of two consecutive years showed that drill sowing produced more paddy yield as compared to broadcast method. 
Muhammad Rizwan et al.

Table-8: Effect of sowing techniques and tillage practices on soil $\mathrm{pH}_{\mathrm{s}}$ at the end of study

\begin{tabular}{|l|c|c|c|c|c|c|}
\hline Treatments & $\begin{array}{c}\text { Broadcasting+ } \\
\text { planking @ 40 kg }\end{array}$ & $\begin{array}{c}\text { \% decrease over } \\
\text { initial value }\end{array}$ & $\begin{array}{c}\text { Broadcasting+ } \\
\text { planking @ 60 kg }\end{array}$ & $\begin{array}{c}\text { \% decrease over } \\
\text { initial value }\end{array}$ & $\begin{array}{c}\text { Drill } \\
\text { sowing }\end{array}$ & $\begin{array}{c}\text { \% decrease over } \\
\text { initial value }\end{array}$ \\
\hline Cultivator & 8.69 & 0.22 & 8.70 & 0.11 & 8.69 & 0.22 \\
\hline $\begin{array}{l}\text { Disk harrow + } \\
\text { Cultivator }\end{array}$ & 8.67 & 0.45 & 8.68 & 0.34 & 8.68 & 0.34 \\
\hline $\begin{array}{l}\text { Rotavator + } \\
\text { Cultivator }\end{array}$ & 8.68 & 0.34 & 8.69 & 0.22 & 8.66 & 0.57 \\
\hline
\end{tabular}

Table-9: Effect of sowing techniques and tillage practices on soil $\mathrm{EC}_{\mathrm{e}}\left(\mathrm{dSm}^{-1}\right)$ at the end of study

\begin{tabular}{|c|c|c|c|c|c|c|}
\hline Treatments & $\begin{array}{c}\text { Broadcasting+ } \\
\text { planking @ 40 kg }\end{array}$ & $\begin{array}{c}\text { \% decrease over } \\
\text { initial value }\end{array}$ & $\begin{array}{c}\text { Broadcasting+ } \\
\text { planking @ 60 kg }\end{array}$ & $\begin{array}{c}\text { \% decrease over } \\
\text { initial value }\end{array}$ & $\begin{array}{c}\text { Drill } \\
\text { sowing }\end{array}$ & $\begin{array}{c}\text { \% decrease over } \\
\text { initial value }\end{array}$ \\
\hline Cultivator & 3.82 & 6.14 & 3.87 & 4.91 & 3.81 & 6.38 \\
\hline $\begin{array}{c}\text { Disk harrow + } \\
\text { Cultivator }\end{array}$ & 3.55 & 12.77 & 3.64 & 10.56 & 3.52 & 13.51 \\
\hline $\begin{array}{c}\text { Rotavator + } \\
\text { Cultivator }\end{array}$ & 3.42 & 15.97 & 3.53 & 13.26 & 3.41 & 16.21 \\
\hline
\end{tabular}

Table-10: Effect of sowing techniques and tillage practices on soil SAR at the end of study

\begin{tabular}{|c|c|c|c|c|c|c|}
\hline Treatments & $\begin{array}{c}\text { Broadcasting+ } \\
\text { planking @ 40 kg }\end{array}$ & $\begin{array}{c}\text { \% decrease over } \\
\text { initial value }\end{array}$ & $\begin{array}{c}\text { Broadcasting+ } \\
\text { planking @ 60 kg }\end{array}$ & $\begin{array}{c}\text { \% decrease over } \\
\text { initial value }\end{array}$ & $\begin{array}{c}\text { Drill } \\
\text { sowing }\end{array}$ & $\begin{array}{c}\text { \% decrease over } \\
\text { initial value }\end{array}$ \\
\hline Cultivator & 28.38 & 5.77 & 28.63 & 4.94 & 28.52 & 5.31 \\
\hline $\begin{array}{c}\text { Disk harrow + } \\
\text { Cultivator }\end{array}$ & 28.09 & 6.73 & 28.27 & 6.14 & 27.85 & 7.53 \\
\hline $\begin{array}{c}\text { Rotavator + } \\
\text { Cultivator }\end{array}$ & 27.66 & 8.16 & 28.15 & 6.54 & 27.54 & 8.56 \\
\hline
\end{tabular}

More paddy yield by drill sowing over the broadcasting may be related to the fact that line sowing allows the more effective management of nutrient, water and weed eradication between rows. Seedling emergence with optimum plant density is a very critical factor to achieve the target of good yield for any cropping system. In drill sowing, seeds were sown at a spacing of $20 \mathrm{~cm}$ with depth of 2-3 cm, which facilitate the good seed-to-soil contact, seed absorbs moisture from deeper soil during a dry period (Ohno et al., 2018) resulting in a uniform crop stand. Results of current study demonstrated that maximum number of tillers (203.11) and (209.44) and paddy yield $\left(2.45 \mathrm{t} \mathrm{ha}^{-1}\right)$ and $\left(2.61 \mathrm{t} \mathrm{ha}^{-1}\right)$ were produced by drill sowing in 2015 and 2016 respectively which were significantly higher than broadcast method of sowing. The plausible reason for this increase number of tillers may be that line sowing by drill ensures the uniform distribution of seed, fertilizer and irrigation water and ultimately the crop stand is uniform across the whole field (Kumar and Ladha, 2011). While in broadcast method seeds positioned at different soil depths and often crop stand is not uniform (Xangsayasane et al., 2019). Furthermore, in broadcast sowing, weeds are not effectively controlled (Fukai and Ouk, 2012). Lodging is a very critical problem associated with direct seeded rice (Rickman et al., 1999), however, drill seeding may reduce lodging up to $10 \%$ (Pandey et al., 2002). Jackson et al. (2017) compared the broadcasting and drill sowing methods of direct seeded rice in a field study. They documented that that drill sowing produced more paddy yield of $4590 \mathrm{~kg} / \mathrm{ha}$ against broadcasting with paddy yield of $3490 \mathrm{~kg} / \mathrm{ha}$. Similarly, the yield advantage of drilling was observed over broadcasting by Kumar and Ladha (2011). They also opined that drilling facilitates effective weeding and provides better crop establishment which supported the findings of the current study. On the other hand, broadcasting results in uneven crop establishment (Hayashi et al., 2009).

\section{Conclusion}

In the current study, different tillage implements 
were used for land preparation for sowing of direct seeded rice in a salt affected field. The use of rotavator with cultivator was a more effective tillage practice for improving the soil properties and paddy yield of direct seeded rice in salt affected soils. Among the sowing methods drill sowing was superior to broadcast method. So, it can be concluded that tillage practice with rotavator + cultivator and drill sowing is a very effective and feasible technology for direct seeding of rice in salt affected soils

Disclaimer: None.

Conflict of Interest: None.

Source of Funding: None.

\section{References}

Abdullah Z, Khan MA and Flowers TJ, 2001. Causes of sterility in seed set of rice under salinity stress. J. Agron. Crop Sci. 187: 25-32.

Ahmed K, Qadir G, Jami AR, Nawaz, MQ, Rehim A, Jabran K and Hussain M, 2015. Gypsum and farm manure application with chiseling improve soil properties and performance of fodder beet under saline-sodic conditions. Int. J. Agric. Biol. 17(6): 1225-1230.

Aikins SHM and Afuakwa JJ, 2012. Effect of four different tillage practices on soil physical properties under cowpea. Agric. Biol. J. North Am. 3(1): 17-24.

Amin M, Muhammad JK, Muhammad TJ, Masood R, Javaid AT, Muhammad H and Zahir S, 2014. Effect of different tillage practices on soil physical properties under wheat in semi-arid environment. Soil Environ. 33(1): 33-37.

Amini S, Ghadiri H, Chen C and Marschner P, 2016. Salt-affected soils, reclamation, carbon dynamics, and biochar: A Review. J. Soils Sedi. 16: 939-953.

Ashraf M, Muhammad SS, Manzoor A and Muhammad Y, 2003. Effects of different tillage systems on bulk density and sugarcane yield. Pak. J. Life Soc. Sci. 1(1): 69-71.

Azhar M, Iqbal M, Khan MA and Ashraf M, 2001. Effects of tillage implements in combination with gypsum applications on the reclamation of salinesodic soils. Int. J. Agric. Biol. 3(3): 301-304.

Balasubramanian V, Ladha JK, Gupta RK, Naresh RK, Mehla RS, Bijay S and Yadvinder S, 2003. Technology options for rice in the rice-wheat system in South Asia. In J.K. Ladha et al. (ed.)
Improving the productivity and sustainability of rice-wheat systems: Issues and impact. ASA Spec. Publ. 65. ASA, CSSA, and SSSA, Madison, WI, 2003, 115-147.

Birkas M, Jolankai M, Kisic I and Stipesevic B, 2008. Soil tillage needs a radical change for sustainability. Agric. Conspectus Sci. 73(3): 131136.

Bohn HL, McNeal BL and O'Connor GA, 1985. Soil Chemistry. 2nd ed. John Wiley and Sons, New York.

Castillo EG, Tuong TP, Ismail AM and Inubushi K, 2007. Response to salinity in rice: comparative effects of osmotic and ionic stresses. Plant Prod. Sci. 10: 159-170.

Chauhan BS, Gill G and Preston C, 2006. Tillage system effects on weed ecology, herbicide activity and persistence: A review. Aust. J. Exp. Agric. 46: 1557-1570.

Cha-umi S, Supaibulwattana K and Kirdmanee C, 2009. Comparative effects of salt stress and extreme $\mathrm{pH}$ stress combined on glycinebetaine accumulation, photosynthetic abilities and growth characters of two rice genotypes. Rice Sci. 16: 274-282.

Coats B, 2003. Global rice production. In: Smith CW, Dilday RH (eds) Rice origin, history, technology and production. Wiley, Hoboken, pp 247-470.

Dikinya O, Hinz C and Aylmore G, 2006. Dispersion and re-deposition of fine particles and their effects on saturated hydraulic conductivity. Soil Res. 44: 47-56.

Eynard A, Lal R and Wiebe K, 2005. Crop production in salt-affected soils. J. Sust. Agric. 27: 5-50.

Farshid A and Hassan ER, 2012. Physiological characterization of rice under salinity stress during vegetative and reproductive stages. Indian J. Sci. Tech. 5: 2578-2586.

Fukai S and Ouk M, 2012. Increased productivity of rainfed lowland rice cropping systems of the Mekong region. Crop Pasture Sci. 63(10): 944973.

Gopal R, Jat RK, Malik RK, Kumar V, Alam MM, Jat ML, Mazid MA, Saharawat YS, McDonald A and Gupta R, 2010. Direct dry seeded rice production technology and weed management in rice-based systems. technical bulletin. International Maize and Wheat Improvement Center, New Delhi, India, 28pp.

Guo Y, Huang J, Shi Z and Li H, 2015. Mapping spatial variability of soil salinity in a coastal paddy 
field based on electromagnetic sensors. PloS One 10: $\quad 1-12$. e0127996. doi:10.1371/journal.pone.0127996.

Hamza MA and Anderson WK, 2005. Soil compaction in cropping systems: A review of the nature, causes and possible solutions. Soil Tillage Res. 82: 121-145.

Hayashi S, Kamoshita A, Yamagishi J, Kotchasatit A and Jongdee B, 2009. Spatial variability in the growth of direct-seeded rainfed lowland rice (Oryza sativa L.) in northeast Thailand. Field Crops Res. 11(3): 251-261.

Hoang TML, Tran TN, Nguyen TKT, Williams B, Wrum P, Bellairs S and Mundree S, 2016. Improvement of salinity stress tolerance in rice: challenges and opportunities. Agron. 6 (54): 1-23.

IRRI, 2002. Rice almanac: source book for the most important economic activity on earth. CABI, Wallingford.

IRRI, 2003. Main weeds of rice in Asia. [http://www.knowledgebank.irri.org. Accessed on 5 July 2011.

Jabro JD, Sainju UM, Lenssen AW and Evans RG, 2011. Tillage effects on dryland soil physical properties in northeastern Montana. Commun. Soil Sci. Plant Analysis. 42: 2179-2187.

Jackson T, Sengxua P and Wade LJ, 2017. Croplivestock systems platform for capacity building, testing practices, commercialization and community learning. Canberra, Australia: ACIAR.

James RA, Blake C, Byrt CS and Munns R, 2011. Major genes for $\mathrm{Na}+$ exclusion, $\mathrm{Nax} 1$ and $\mathrm{Nax} 2$ (wheat HKT1;4 and HKT1;5), decrease $\mathrm{Na}^{+}$ accumulation in bread wheat leaves under saline and waterlogged conditions. J. Exp. Bot. 62: 29392947.

Ji B, Zhao Y, Mu X, Liu K and Li C, 2013. Effects of tillage on soil physical properties and root growth of maize in loam and clay in central China. Plant Soil Environ. 59 (7): 295-302.

Jini D and Joseph B, 2017. Physiological mechanism of salicylic acid for alleviation of salt stress in rice. Rice Sci. 24(2): 97-108.

Kaur J and Singh A, 2017. Direct seeded rice: prospects, problems/constraints and researchable issues in India. Curr. Agric. Res. 5(1): 13-32.

Kumar V and Ladha JK, 2011. Direct seeding of rice: Recent developments and future research needs. In D. L. Sparks (Ed.), Advances in agronomy (Vol. 111, pp. 297-413). Academic Press. doi:10.1016/B978-0-12-387689-8.00001-1
Lee KS, Nam JK and Shin HT, 1999. Effective land preparation for wet seeding on a reclaimed saline soil in Korea." Int. Rice Res. Notes. 24: 36.

Licht MA and Al-Kaisi M, 2005. Strip-tillage effect on seedbed soil temperature and other soil physical properties. Soil Tillage Res. 80 (1-2): 233-249.

Maas EV and Hoffman GJ, 1977. Crop salt tolerance current assessment. ASCE J. Irrig. Drain. Div. 103:115-134.

Montoroi JP, Albergel J, Bubos A, Fall M, Sall S, Bernard A, Brunet D, Dubee G and Zante P, 1993. "Rehabilitation of rice fields in the acid sulphate soils of lower Casamance, Senegal." In Symposium on Acid Sulphate Soils. International Institute for Land Reclamation and Improvement, Wageningen, Netherlands.

Moon YH, Kwon YR, Ahn BK, Kim DH and Han SS, 2011. Impact of compost application on improvement of rice productivity and quality in reclaimed soil. Korean J. Soil Sci. Ferti. 44: 808813. (In Korean).

Moradi F, Ismail AM, Gregorio GB and Egdane JA, 2003. Salinity tolerance of rice during reproductive development and association with tolerance at the seedling stage. Ind. J. Plant Physiol. 8: 105-116.

Mosaddeghi MR, Mahboubi AA and Safadoust A, 2009. Short-term effects of tillage and manure on some soil physical properties and maize root growth in a sandy loam soil in western Iran. Soil Till. Res. 104(1): 173-179.

Munns R and Tester M, 2008. Mechanisms of salinity tolerance. Ann. Rev. Plant Biol. 59: 651-681.

Nam JK and Kwon TO, 1999. Influence of tillage methods on the growth and yield of rice for direct seeding on wet paddy surface of reclaimed saline land. J. Life Sci. Nat. Res. 21: 22-40. (In Korean).

Nayel MH, Farid EAE, Mohamed HD and Abdel Rahman AE, 2016. The effect of tillage system on soil physical properties in eddammer locality of northern Sudan. Ann. Agric. Environ. Sci. 02: 2734.

Nishimura T, Cha-um S, Takagaki M and Ohyama K, 2011. Survival percentage, photosynthetic abilities and growth characters of two indica rice (Oryza sativa L. spp. indica) cultivars in response to isosmotic stress. Span. J. Agric. Res. 9: 262-270.

Ohno H, Banayo NPMC, Bueno CS, Kashiwagi J, Nakashima T, Corales MA and Kato Y, 2018. Longer mesocotyl contributes to quick seedling establishment, improved root anchorage, and early 
vigor of deep-sown rice. Field Crop Res. 228: 8492.

Pandey S, Mortimer M, Wade L, Tuong TP, Lopez K and Hardy B, 2002. Direct seeding: research issues and opportunities. Proceedings of the International Workshop on Direct Seeding in Asian Rice Systems: Strategic Research Issues and Opportunities, 25-28 January 2000, Bangkok, Thailand. Los Baños (Philippines): International Rice Research Institute. 383 p.

Pathak H, Tewari AN, Sankhyan S, Dubey DS, Mina U, Virender KS, Jain N and Bhatia A, 2011. Direct-seeded rice: Potential, performance and problems - A review. Curr. Adv. Agric. Sci. 3(2): 77-88.

Pearce AD, Dillon CR, Keisling TC and Wilson CE, 1999. Economic and agronomic effects of four tillage practices on rice produced on saline soils. J. Prod. Agric. 12: 305-312.

Pearson GA, 1959. Factors influencing salinity of submerged soils and growth of caloro rice. Soil Sci. 87: 198-206.

Rickman JF, Pyseth M, Bunna S and Sinath P, 1999. Direct seeding of rice in Cambodia. CambodiaIRRI-Australia Project, Phnom Penh, Cambodia. (Unpublished.)

Rizwan M, Khalil A, Muhammad N, Muhammad FN, Muhammad QN, Sarfraz N, Muhammad A, Adnan U and Imtiaz AW, 2019. Effect of nitrogen application methods and tillage implements on wheat production in salt affected soils. Int. J. Biol. Sci. 15 (6): 194-201.

Rizwan M, Khalil A, Muhammad S, Muhammad QN, Ghulam Q, Muhammad U and Muhammad WI, 2018. Managing sesbania decomposition with urea and different tillage techniques in salt affected soil. Int. J. Biol. Sci. 12 (6): 258-268.

Sadiq M, Jamil M, Mehdi SM, Hassan G and Akhtar A, 2002. Effect of different tillage implements on wheat production in rice-wheat cropping system in saline-sodic soil. Pak. J. Agron. 1(2-3): 98-100.

Sarkar RK, Sanjukta D and Das S, 2003. Yield of rainfed lowland rice with medium water depth under anaerobic direct seeding and transplanting. Trop. Sci. 43: 192-198.

Sengxua P, Jackson T, Simali P, Vial LK, Douangboupha K, Clarke E and Wade LJ, 2019. Integrated nutrient-weed management under mechanised dry direct seeding (DDS) is essential for sustained smallholder adoption in rainfed lowland rice (Oryza sativa L.). Exp. Agric. 55(4):
509-525.

Singh TP, 2008. Performance of no-till drill for establishment of rice and it's comparison with drum seeder and conventional method. Tech. Sci. 11:12-20.

Siringam K, Juntawong N, Cha-um S and Kirdmanee C, 2011. Salt stress induced ion accumulation, ion homeostasis, membrane injury and sugar contents in salt-sensitive rice (Oryza sativa L. spp. indica) roots under isosmotic conditions. Afr. J. Biotech. 10: $1340-1346$.

Steel RGD, Torrie JH and Dickey DA, 1997. Principles and Procedures of Statistic: A Biometrical Approach. 3rd edition, pp: 400-428. Mc Graw Hill Book Co. Inc. New York, USA.

Sweeney DW, Kirkham MB and Sisson JB, 2005. Crop and soil response to wheel-track compaction of a clay pan soil. Agron. J. 98(3): 637-643.

Tuong TP and Bouman BAM, 2003. Rice production in water-scarce environments. In: Proc Water Productivity Workshop, 12-14 November 2001, Colombo, Sri Lanka. International Water Management Institute, Colombo, Sri Lanka.

US Salinity Laboratory Staff, 1954. Diagnosis and Improvement of Saline and Alkali Soils. USDA Handbook 60, Washington, DC, USA.

Wilson CE, Keisling JTC, Miller DM, Dillon CR, Pearce AD, Frizzell DL and Counce PA, 2000. Tillage influence on soluble salt movement in silt loam soils cropped to paddy rice. Soil Sci. Soc. Am. J. 64: 1771-1776.

Xangsayasane P, Senthong P, Chea V, Makara O, Chay B, Jaquie M and Shu F, 2019. A diagnostic on-farm survey of the potential of seed drill and transplanter for mechanized rice establishment in Central Laos and Southern Cambodia. Plant Prod. Sci. 22 (1): 12-22.

Xiong X, Azuma A, Huijun Z, Ken A, Chinao T, Kazuhiko O, Feng L, Huibin J, Chunfeng Z, Baoguo Z, Nannan W, Qingying M and Shucun Y, 2012. Improvement of salt-affected soils by deep tillage. Eng. Agric. Environ. Food. 5(1): 29-35.

Zeng L and Shannon MC, 2000. Effects of salinity on grain yield and yield components of rice at different seeding densities. Agron. J. 92: 418-423.

Zhao C, Jiang H, Ren C, Yin Y and Li Y, 2007. Studies on key techniques of sowing rice directly on dry land for high yield and high efficiency. J. Jilin. Agric. Sci. 32: 9-11 (In Chinese with English abstract).

Zhu L, 2008. A report on dry direct seeding cultivation 
technique of early rice. J. Guangxi Agric. 23: 1011 (In Chinese with English abstract).

\section{Contribution of Authors}

Rizwan M: Conceived the idea, conducted the study for two years, literature review and manuscript writing

Ahmed K, Bhatti MK \& Naseem AR: Literature review, data interpretation and manuscript writing Sarfraz M: Literature review, manuscript final reading and approval

Irfan M \& Hussain SS: Data collection and statistical analysis 